\title{
DIE SUID-AFRIKAANSE AKADEMIE VIR WETENSKAP EN KUNS \\ 7de Jaarlikse Simposium vir Nagraadse Studente in die Natuurwetenskappe \\ 2 November 2007, Tshwane Universiteit van Tegnologie
}

\section{Die bestudering van 1-hidroksietilideen-1,1-difosfoniese suur en sy komplekse met behulp van Raman- en KMR-spektroskopie}

\author{
W. BARNARD \\ Departement Chemie, Universiteit van Pretoria, Lynnwood, Pretoria 0002 \\ werner.barnard@up.ac.za.
}

1-hidroksietilideen-1,1-difosfoniese suur (HEDP) is 'n tetraprotiese suur wat verskillende $\mathrm{pH}$-afhanklike vorms soos $\mathrm{H}_{4} \mathrm{~L}, \mathrm{H}_{3} \mathrm{~L}-\mathrm{H}_{2} \mathrm{~L}^{2-}, \mathrm{HL}^{3-}$ en $\mathrm{L}^{4-}$ in oplossing kan hê. HEDP word gereeld gebruik as 'n pynverdower vir beenkanker en ook as 'n komplekserende ligand met sekere radioaktiewe isotope vir die behandeling van beenkanker. Verskillende HEDP-konsentrasies is by hidroksiapatiet ('n model van been) en $\mathrm{CaHPO}_{4}$ gevoeg, en die vorming van Ca-HEDP-komplekse is met Raman-spektroskopie gevolg. Daar is bevind dat die interaksies dieselfde is as dié met bees-been.

Twee Ca-HEDP-komplekse is waargeneem. Die een is geïdentifiseer as die $\mathrm{CaH}_{2} \mathrm{~L}$-spesie en die ander een is moontlik CaHL: Die vorming van die anioniese vorms van HEDP in oplossing tydens titrasie met $\mathrm{NaOH}$ oor die $\mathrm{pH}$-gebied van 1.00-13.00 is deur middel van Raman-spektroskopie en ${ }^{31} \mathrm{P}$ en ${ }^{23} \mathrm{Na}$ KMR-spektroskopie gevolg. Dit het die identifisering van $\mathrm{L}^{4-}, \mathrm{HL}^{3-}$, en $\mathrm{H}_{2} \mathrm{~L}^{2-}$-spesies moontlik gemaak. Daar was geen inmenging van $\mathrm{Na}^{+}$nie, omdat geen verskuiwing in die Raman P-O-bandposisie en ook geen onverklaarbare verskuiwing in die ${ }^{23} \mathrm{Na}$ KMR-data waargeneem is nie. $\mathrm{Die}^{31} \mathrm{P}$ KMR-verskuiwings het goed met die tendens soos waargeneem in die Raman-spektra vergelyk maar, soos verwag, was dit nie moontlik om duidelik met KMR tussen spesies te onderskei nie.

The investigation of 1-hydroxyethylidene-1,1-diphosphonic acid and its complexes by Raman and NMR spectroscopy

1-hydroxyethylidene-1,1-diphosphonic acid (HEDP) species and complexes were monitored by means of Raman spectroscopy, at the solid/solution interface with hydroxyapatite, $\mathrm{CaHPO}_{4}$ and bovine bone. In a $\mathrm{NaOH}$-titrated solution, the additional techniques ofEDPHE ${ }^{31} \mathrm{P}$ and ${ }^{23} \mathrm{Na} \mathrm{NMR}$ spectroscopy were used to identify various protonated forms of HEDP. 


\title{
Die ontwikkeling van 'n kragtige piko-sekonde-laser vir maan-laserafstandsmeting
}

\author{
R.C. Вотна \\ Ruimtegeodesieprogram, Hartebeesthoek Radio Astronomie Observatorium, \\ Posbus 443, Krugersdorp 1740 \\ roelf@iisgeo.org
}

Satelliet-laserafstandsmeting (SLAM) het in die laaste paar jaar tot nuwe vlakke van akkuraatheid ontwikkel. Daarmee saam het ook die strewe om afstandsmeting na die maan te kan doen ontstaan. Die huidige ontwikkeling van 'n maan-laserafstandsmeter (MLAM) deur die Ruimtegeodesieprogram by Hartebeesthoek Radio Astronomie Observatorium (HartRAO) is een van die grootste projekte wat tans onderneem word.

'n Tipiese SLAM-stelsel werk op die beginsel dat kort laser-pulse in die rigting van 'n satelliet geskiet word, dit daar teruggekaats word en dat hierdie puls weer by die meetinstrument gemeet word. Die tydsduur vandat die laser-puls die instrument verlaat het totdat die gereflekteerde puls weer by die meetinstrument arriveer, word gemeet. Deur hierdie ligbewegingstyd tesame met verskeie ander faktore soos die atmosfeerdigtheid te meet, kan die afstand tussen die instrument en die satelliet akkuraat bepaal word.

Die MLAM wat tans ontwikkel word, kan egter om verskeie redes nie net 'n vergrote weergawe van 'n tipiese SLAM wees nie. Die ooreenkoms eindig by die feit dat 'n mens vanaf (onder andere) 'n tydsmeting, 'n afstand akkuraat kan bepaal. Die hele metodiek — van hoe die instrument werk, en die frekwensies waarteen gewerk word, tot by hoe die gereflekteerde puls weer gemeet word — verskil drasties tussen die twee stelsels. Hierdie faktore veroorsaak dat 'n totale herontwerp van die laserafstandsmeterstelsel nodig is, veral as in ag geneem word dat dit ons ideaal is om die afstand akkuraat tot $3 \mathrm{~mm}$ te bepaal.

'n Belangrike deel wat deur die herontwerp geraak word, is die laser-substelsel. Bo en behalwe die hoër energie per puls wat die laser moet lewer, moet dit ook binne uiters kort pulse gekompakteer wees. Die spesifieke ontwerpspesifikasies is huidig > $100 \mathrm{~mJ}$ per puls met 'n lengte van $20 \mathrm{ps,} \mathrm{met} \mathrm{'n}$ beheerbare pulsherhalingstempo van 500 tot $2 \mathrm{kHz}$. Die hoër energie is nodig omdat die maan gemiddeld $352000 \mathrm{~km}$ vanaf die aarde is, terwyl satelliete gewoonlik binne 500 - 36000 km vanaf die aarde se oppervlakte lê. Die korter pulse word benodig omdat slegs 'n enkele foton moontlik per laserpuls terugontvang word. Meestal word niks gemeet nie, omdat die laserpuls dié astronomiese afstand moet aflê voordat dit weer gemeet kan word. Die pulsherhalingstempo van SLAM stelsels is $5 \mathrm{~Hz}$, omdat hulle volledige pulse vanuit die gereflekteerde lig kan meet. Aangesien slegs enkele fotone met die MLAM gemeet kan word, is dit noodsaaklik om 'n baie hoër pulsherhalingstempo te gebruik; anders sal geen nuttige data uit die eksperiment voortvloei nie.

'n Bondige opsomming van die tegnieke van SLAM en MLAM, waarin die relevante verskille uitgelig word, word gegee. Die algemene stelselontwerp en spesifikasies word daarna bespreek. Hierna word daar op die laser-substelsel gefokus. Spesifieke aandag word gegee aan die moontlike soorte lasers, asook ontwerpe, waarop daar tans op beide die teoretiese en praktiese navorsingsvlak gefokus word.

\section{The development of a high-power pico-second laser for lunar laser ranging}

Satellite laser ranging (SLR) has evolved to higher accuracies and the aspiration to perform lunar laser ranging (LLR). A LLR system cannot be a scaled-up version of a SLR, due to various reasons. A total system redesign is required, especially for the laser subsystem. 


\title{
Skeiding van $\mathrm{Zr}$ en $\mathrm{Hf}$ deur fraksionele kristallisasie van $\mathrm{K}_{2} \mathrm{Zr}(\mathrm{Hf}) \mathrm{F}_{6}: 2$ 'n teoretiese en eksperimentele studie
}

\author{
D.J. Branken ${ }^{1}$, G. Lachmann ${ }^{1}$, H.M. Krieg ${ }^{* 2}$ en O.S.L. Bruinsma ${ }^{2}$ \\ ${ }^{1}$ Skool vir Chemie, Noordwes Universiteit, Privaatsak X6001, Potchefstroom 2520 \\ ${ }^{2}$ Skool vir Chemiese en Mineraal Ingenieurswese, Noordwes Universiteit, Privaatsak X6001, \\ Potchefstroom 2520 \\ *henning.krieg@nwu.ac.za
}

Sirkonium-metaal $(\mathrm{Zr})$ van hoë suiwerheid word in die vorm van $2 \mathrm{n}$ allooi in kernreaktors gebruik. ${ }^{1} \mathrm{Zr}$ word egter altyd saam met hafnium (Hf) in die natuur aangetref en omdat Hf, in teenstelling met Zr, 2 $\mathrm{n}$ hoë absorpsievermoë vir termiese neutrone besit, moet die twee elemente van mekaar geskei word. Om Zr met 2 'n lae Hf-inhoud (<100 ppm Hf) te produseer, word komplekse skeidingsmetodes egter benodig, aangesien $\mathrm{Zr}$ en $\mathrm{Hf}$ se chemiese eienskappe baie ooreenstem. ${ }^{2}$

Die primêre bron van $\mathrm{Zr}$ is sirkoonerts $\left(\mathrm{ZrSiO}_{4}\right)$, wat ongeveer $1 \% \mathrm{Hf}$ relatief tot $\mathrm{Zr}$ bevat. Sirkoon is chemies inert en $\mathrm{Zr}$ kan uit die mineraal ontgin word deur chlorinering in die teenwoordigheid van koolstof, om $\mathrm{Zr}(\mathrm{Hf}) \mathrm{Cl}_{4}$ te produseer. $\mathrm{Zr}$ en $\mathrm{Hf}$ kan dan geskei word deur distillasie in gesmelte $\mathrm{KCl} /$ $\mathrm{AlCl}_{3}$ in die CEZUS-proses, of deur vloeistof-vloeistof-ekstraksie in die MIBK-proses. Die smelting van die erts met $\mathrm{NaOH}$ - waar $\mathrm{Zr}$ en Hf geskei kan word deur vloeistof-vloeistof-ekstraksie met tributielfosfaat in keroseen, in die TBP-proses - word ook gebruik.

In die plasmaproses, ontwikkel deur Necsa, ${ }^{3}$ word die chemies inerte sirkoon se kristalstruktuur afgebreek en deur verhitting in 'n plasma-oond na 'n amorfe silikafase omgeskakel. Hierdie plasmagedissosieerde sirkoon (PGS) is chemies meer reaktief, waardeur $\mathrm{K}_{2} \mathrm{ZrF}_{6}$ deur verdere chemiese prosessering geproduseer kan word. Die sout bevat egter steeds ongeveer $1 \% \mathrm{Hf}$, en $2 \mathrm{n}$ moontlike skeidingsmetode is die fraksionele kristallisasie van $\mathrm{K}_{2} \mathrm{ZrF}_{6}$ en $\mathrm{K}_{2} \mathrm{HfF}_{6}$, aangesien die oplosbaarheid van die twee soute verskil. ${ }^{4}$ Ongeveer 16 tot 18 herkristallisasies van die sout uit waterige oplossing(s) is egter nodig om die twee soute doeltreffend van mekaar te skei.

Tydens kristallisasie uit onsuiwer oplossings kan onsuiwerhede deur verskeie meganismes in die produk ingesluit word. Die vorming van mengkristalle deur die substitusie van onsuiwerheidmolekules in die kristalstruktuur van die produk kan egter die dominerende meganisme wees wanneer die gewenste produk en die onsuiwerheid dieselfde molekulêre en kristalstruktuur besit. Dit mag die rede wees waarom daar ' $n$ groot aantal herkristallisasies nodig is om $\mathrm{K}_{2} \mathrm{ZrF}_{6}$ en $\mathrm{K}_{2} \mathrm{HfF}_{6}$ te skei.

Die verdeling van die onsuiwerhede tussen die vloeistof- en die vastestoffase (kristal) word deur die termodinamika van die entiteite in oplossing sowel as dié van die vastestoffase bepaal. Die mate waartoe onsuiwerhede in die kristalstruktuur ingebou word, word dus bepaal deur die energieverandering wat tydens die vorming van mengkristalle plaasvind.

In hierdie studie word molekulêre modellering, en meer spesifiek CASTEP, wat op digtheidfunksionaalteorie gebaseer is, gebruik om die vormingsenergie en daarom die termodinamiese stabiliteit van $\mathrm{K}_{2} \mathrm{Zr}_{(1-x)} \mathrm{Hf}_{\mathrm{x}} \mathrm{F}_{6}$ met verskillende Hf-konsentrasies (x) te bepaal. Hierdie data kan gebruik word om die doeltreffendheid van die skeiding van $\mathrm{Zr}$ en Hf met behulp van $2 \mathrm{n}$ kristallisasieproses van $\mathrm{K}_{2} \mathrm{Zr}(\mathrm{Hf}) \mathrm{F}_{6}$, teoreties te voorspel. Verder word die fraksionele kristallisasie van $\mathrm{K}_{2} \mathrm{Zr}(\mathrm{Hf}) \mathrm{F}_{6}$ ook eksperimenteel bestudeer om die doeltreffendheid van die proses te bepaal, asook om vas te stel of daar 'n ooreenkoms bestaan tussen die eksperimentele data en die resultate wat uit molekulêre modellering verkry word. 


\title{
Verwysings
}

1. Nielsen, R.H., Schlewitz, J.H., Nielsen, H. 2001. Kirk-Othmer Encyclopaedia of chemical technology, $5^{\text {th }}$ ed, John Wiley. Chapter 26:621-664.

2. Poriel, L., Favre-Réguillon, A., Pellet-Rostaing, S., Lemaire, M. 2006. Zirconium and hafnium separation, part 1. Liquid/liquid extraction in hydrochloric acid aqueous solution with aliquat 336. Separation Science and Technology, 41:1927-1940.

3. Nel, J.T. 1999. Process of reacting zirconium-based material. U.S. Patent. 5958355. Sep 28.

4. Vinarov, I.V. 1967. Modern methods of separating zirconium and hafnium. Russian Chemical Reviews, 36(7):522-536.

\section{Separation of $\mathrm{Zr}$ and $\mathrm{Hf}$ by means of fractional crystallisation of $\mathrm{K}_{2} \mathrm{Zr}(\mathrm{Hf}) \mathrm{F}_{6}$ : a theoretical and experimental study}

Molecular modelling is used to determine whether the formation of $\mathrm{K}_{2} \mathrm{Zr}_{(1-\mathrm{x})} \mathrm{Hf}_{\mathrm{x}} \mathrm{F}_{6}$ solid solutions, which could hamper the separation of $\mathrm{K}_{2} \mathrm{ZrF}_{6}$ and $\mathrm{K}_{2} \mathrm{HfF}_{6}$ by fractional crystallisation, are thermodynamically stable. Fractional crystallisation of $\mathrm{K}_{2} \mathrm{ZrF}_{6}$ and $\mathrm{K}_{2} \mathrm{HfF}_{6}$ are also studied experimentally to determine whether a correlation exists between experimental and molecular modelling results.

\section{Luminesserende eienskappe van $\mathrm{Y}_{2} \mathrm{SiO}_{5}$ :Ce nano-dunlagies}

\author{
E. Coetsee*1, J.R. Botha**2, J.J. Terblans ${ }^{1}$, H.C. Swart ${ }^{1}$ \\ ${ }^{1}$ Departement Fisika, Universiteit van die Vrystaat, Posbus 339, Bloemfontein 9300 \\ ${ }^{2}$ Departement Fisika, Nelson Mandela Metropolitaanse Universiteit, Posbus 77000, \\ Port Elizabeth 6001 \\ *coetseee.sci@ufs.ac.za \\ **reinhardt.botha@nmmu.ac.za
}

Die luminesserende eienskappe van yttriumsilikaat-dunlagies wat met serium gedoteer is $\left(\mathrm{Y}_{2} \mathrm{SiO}_{5}: \mathrm{Ce}\right)$, is ondersoek vir moontlike toepassings in lae-spanning veldemissie-vertooneenhede (FEDs). $\mathrm{Y}_{2} \mathrm{SiO}_{5}$ : $\mathrm{Ce}$ is ' $\mathrm{n}$ blou, luminesserende seldsameaarde-fosfor wat as ' $\mathrm{n}$ alternatief ondersoek word vir die tradisionele blou sinksulfied ( $\mathrm{ZnS}$ )-fosfor. Uniforme, nanometer-dik fosfor-dunlagies is gegroei deur van die pulserende laser neerslagtegniek (PLD) $(\mathrm{KrF} \lambda=248 \mathrm{~nm})$ gebruik te maak. Die vorming van deeltjies tydens die PLD-proses is een van die grootste probleme met hoë-intensiteit optiese toestelle. Een van die oplossings is optimering van die proses-gekoppelde parameters (gasdruk, afstand tussen die voorwerp en die substraat, substraattemperatuur, pulsfrekwensie, energie per puls, laser tydvloed en die aantal pulse) tydens die groei van hierdie dun lagies).

Die dun lagies is sistematies in 'n vakuum gegroei $\left(5 \times 10^{-6}\right.$ Torr), met 'n gasdruk van 1 Torr $\mathrm{O}_{2}$ en

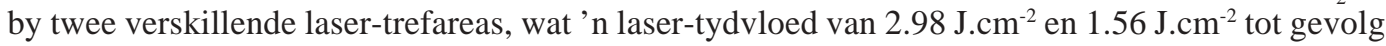
gehad het. Die afstand tussen die voorwerp en die substraat was $4 \mathrm{~cm}$ en die substraat-temperatuur was $600{ }^{\circ} \mathrm{C}$. ' $\mathrm{n}$ Laserpulsfrekwensie van $8 \mathrm{~Hz}, 250 \mathrm{~mJ}$ energie per puls, en 4000 laserpulse is gebruik om die lagies te groei. Die oppervlak-morfologie is met 'n skandeerelektronmikroskoop (SEM), energiedispersiespektroskoop (EDS), atoomkragmikroskoop (AFM) en met X-straaldiffraksie (XRD) geanaliseer. Katode - (CL) en fotonluminessensie (PL)-metings is ook op die dun lagies gedoen.

SEM-, EDS- en AFM-resultate toon 'n uniforme $\mathrm{Y}_{2} \mathrm{SiO}_{5}$ :Ce-lagie wat in 'n vakuum gegroei is, en 'n nanodeeltjie-lagie wat by 'n gasdruk van 1 Torr $\mathrm{O}_{2}$ gegroei is. Die 1 Torr $\mathrm{O}_{2}$ veroorsaak' $n$ growwer 
oppervlakte, vergeleke met die uniforme lagie wat in 'n vakuum gegroei is. AFM-resultate is ook gebruik om ' $n$ aanduiding van die dikte van die uniforme lagie, asook die deeltjiedigtheid van die nano-lagies te bepaal. Die hoër laser-tydvloed het tot die vorming van 'n dikker uniforme lagie gelei, en tot 'n hoër deeltjiedigtheid.

Die growwer oppervlakte van die nano-deeltjies het 'n hoër CL- en PL-intensiteit as die uniforme lagie. Dit is as gevolg van meer lig wat intern in die uniforme lagies teruggekaats word. Die hoër tydvloed lewer ook hoër PL- en CL-intensiteite.

\title{
Luminescent properties of $\mathrm{Y}_{2} \mathrm{SiO}_{5}$ :Ce nano-thin films
}

Process parameters for pulsed-laser deposition (PLD) were investigated for the growth of uniform cerium-doped yttrium silicate $\left(\mathrm{Y}_{2} \mathrm{SiO}_{5}: \mathrm{Ce}\right)$ thin films of phosphor, for possible applications in fieldemission display units (FEDs). An $\mathrm{O}_{2}$ pressure of 1 Torr and a higher fluence resulted in greater luminescence intensity.

\section{'n Studie van turbulensie in akkresieskywe van dwergnovas en die invloed daarvan as 'n sneller vir uitbarstings}

\author{
M. Erwee* en P.J. Meintjes \\ Departement Fisika, Universiteit van die Vrystaat, Posbus 339, Bloemfontein 9300 \\ *mariettez@gmail.com
}

Die doel van hierdie studie is om te bewys dat turbulente bewegings in die buiterand van akkresieskywe van kataklismiese veranderlikes bestaan en verantwoordelik vir dwergnova-uitbarstings is.

Daar word aan die hand gedoen dat hidrodinamiese turbulensie gegenereer word by die warm kol waar die inkomende stroom gas die buiterand van die skyf binnedring. Die turbulente bewegings binne-in die skyf help met die verhoging in viskositeit, deurdat dit die uitwaartse beweging van hoekmomentum en die inwaartse vloei van gas aanhelp. Die teenwoordigheid van turbulensie word moontlik gemaak deurdat die tydsinterval wat dit vir turbulente energie neem om tot op die dissipatiewe vlak af te breek, langer is as die tyd wat nodig is vir die Kepler-beweging om die turbulente bewegings te kanselleer. Sodra die turbulente energie tot op die dissipatiewe vlak afgebreek het, kan dit nie in die gas verdwyn nie, soos wat die geval sou wees in materiaal met ' $n$ hoër viskositeit. Daarom bou die energie op, totdat die hele skyf later turbulent is.

Die kern van hierdie studie behels navorsing om die ligkurwes van kataklimiese veranderlikes wat tekens van flikkering bevat, vir leidrade van die Kolmogorov-energiespektrum te ondersoek. Die data van die ligkurwes word omgeskakel ten einde 'n energiespektrumgrafiek voor te stel, in die hoop om 'n reguit lyn met gradiënt van $-5 / 3$ te verkry, soortgelyk aan die vorm van die energiespektrum van 'n turbulente veld. Verder is dit duidelik dat daar geen dwergnovas met orbitale periodes van minder as 1,3 ure is nie. Die rede vir die afwesigheid van dwergnova-aktiwiteit in hierdie klein sisteme word ook ondersoek. Dit kan moontlik verband hou met die magnetiese veld van die wit dwerge in die sisteme. As die sisteem te klein word, begin die magnetiese veld met skyfvorming inmeng. As geen skyf gevorm word nie, kan geen turbulensie plaasvind nie, en sodoende ook geen uitbarstings, wat kenmerkend van dwergnovas is nie. 


\title{
A study of accretion disc turbulence in dwarf novae and its influence as a trigger of accretion disc eruptions
}

The aim of this study is to prove that turbulent motions in the outer regions of accretion discs of cataclysmic variables (CVs) are responsible for the occurrence of dwarf nova outbursts. It is suggested that hydrodynamic turbulence is generated at the hot spot where the incident gas stream pierces the outer disc.

\section{Woordafbrekingstegnieke vir die Germaanse tale}

\author{
M. FICK \\ Departement Besluitkunde, Universiteit van Suid-Afrika, Posbus 392, Unisa 0003 \\ fickm@unisa.ac.za
}

Aangesien teks in tydskrifte en koerante in smal kolomme gedruk word, word woordafbreking dikwels gebruik om aanvaarbare woordspasiëring en bladsy-uitleg te verkry. In die Germaanse tale soos Duits, Nederlands en Afrikaans word saamgestelde woorde aanmekaar geskryf. In sulke tale word nuwe woorde voortdurend geskep deur woorde saam te voeg. Hoe langer woorde word, hoe meer dikwels moet hulle afgebreek word.

Vir 'n rekenaar is 'n woord bloot 'n string karakters. Dit het geen aanduiding van waar die verskillende dele van saamgestelde woorde begin of eindig nie. Bestaande woordafbrekingstegnieke is nie betroubaar nie en dit is steeds nodig om teks per hand vir woordafbrekingsfoute na te gaan voordat 'n koerant of tydskrif gedruk word. Daar bestaan dus 'n groot behoefte aan 'n "intelligente", betroubare woordafbrekingstegniek vir Afrikaans en ander Germaanse tale.

Verskeie woordafbrekingstegnieke is reeds ontwerp om hierdie probleem aan te spreek. In 'n poging om 'n alternatiewe algoritme te ontwerp, is 'n studie aangepak waarin bestaande metodes ontleed word om vas te stel wat hulle sterk en swak punte is. Twee van hierdie tegnieke word in hierdie voorlegging bespreek, naamlik kunsmatige neurale netwerke en Frank Liang se algoritme wat vir TeX ontwikkel is.

Kunsmatige neurale netwerke is deur die werking van die menslike brein geïnspireer. Kunsmatige neurale netwerke is veral geskik vir patroonherkenning en is dus ' $n$ goeie tegniek vir die probleem van woordafbreking wat op patroonherkenning berus. 'n Neurale netwerk vir woordafbreking kan afgerig word om patrone wat uit korrek afgebreekte woorde gegenereer is, te herken. So 'n neurale netwerk is in staat om ook woorde wat dit nog nie teëgekom het nie, af te breek.

Die algoritme wat vir TeX ontwikkel is, is op patroonontleding gebaseer. Woordelyste waarin korrekte woordafbreking aangedui is, word deur die program OPATGEN in patrone (of subwoorde) van verskillende lengtes opgebreek en waardes word volgens afbrekingsgeldigheid toegeken. Die patrone word in 'n kompakte datastruktuur gepak, waar dit effektief opgespoor kan word. Die algoritme gebruik hierdie datastruktuur om die betrokke patrone vir'n spesifieke woord op te soek, en volgens die toegekende waardes te bepaal waar die woord afgebreek moet word.

\section{Hyphenation techniques for the Germanic languages}

In Germanic languages where combined words are written as one word, electronic hyphenation remains an unsolved problem. Existing hyphenation techniques are not reliable. In an effort to develop an alternative technique, existing techniques like artificial neural networks and Liang's algorithm for TeX are analysed. 


\title{
Gepulseerde laserdeponering van platinum-gebaseerde allooie
}

\author{
R.A. Harris*, H.C. Swart en J.J. Terblans \\ Departement Fisika, Universiteit van die Vrystaat, Posbus 339, Bloemfontein 9300 \\ *harrisra.sci@ufs.ac.za
}

Gepulseerde laserdeponering (PLD) is 'n redelik aanpasbare tegniek vir die groei van dun lagies. Die tegniek kan in beginsel gebruik word om dun lagies van byna alle vaste stowwe, insluitend hoësmeltpuntmetale en metaalallooie, te groei. Die karaktereienskappe van die gepulseerde laserdeponering (by $248 \mathrm{~nm}$ ) van metaalallooie is: (1) hoë deponeringstempo's van tot $3 \mathrm{~nm} / \mathrm{s}$ (indien die verbrandingsdrumpel van $5 \mathrm{~J} / \mathrm{cm}^{2}$ oorskry word), (2) stoigiometriese oordrag tussen die teiken en die lagie, en (3) druppeltjies op die lagie se oppervlakte. Die bestudering van platinum (Pt)-gebaseerde allooie in hoë temperatuur omgewings het in die laaste paar jaar groot aandag geniet, veral weens die allooie se goeie korrosie- en oksidasie-weerstandbiedende eienskappe. Die mikrostruktuur van Ptgebaseerde allooie is baie dieselfde as dié van nikkel (Ni)-gebaseerde superallooie, met $\mathrm{Pt}_{3} \mathrm{Al}$-fases in 'n Pt-matriks. Die belangrikste verskille tussen die Ni-gebaseerde en Pt-gebaseerde allooie is: (1) die veel hoër smeltpunt van die Pt-gebaseerde allooie $\left(1769^{\circ} \mathrm{C}\right.$ vir $\mathrm{Pt}$, teenoor $\mathrm{Ni}$ se $\left.1455^{\circ} \mathrm{C}\right)$ en (2) die groter korrosieweerstandbiedendheid van die Pt-gebaseerde allooie. Die stoigiometriese oordrag tussen die teiken en die substraat gedurende PLD is veral van belang in hierdie studie, waartydens die Pt-gebaseerde superallooi $\mathrm{Pt}_{86} \mathrm{Al}_{11} \mathrm{Cr}_{3} \mathrm{Ru}_{2}$ as ' $\mathrm{n}$ dun lagie gedeponeer moes word, met die doel dat die superallooi se eienskappe behoue moes bly. Dit was dus belangrik dat daar ook nie 'n verandering in die mikrostruktuur van die gedeponeerde dun lagie tydens die PLD-proses moes wees nie. Desnieteenstaande is een van die groot probleme met PLD die grofheid van die teikenoppervlakte. Dit veroorsaak die ontstaan van druppeltjies (met groottes wat tot verskeie ìm strek) in en op die groeiende dun lagie. Die druppelvorming is afhanklik van die basisdruk van die atmosfeer en die tipe gasse in die atmosfeer tydens die PLD-proses. Die hoofdoel van hierdie studie is die kwantifisering van druppelvorming tydens PLD as 'n funksie van die tipe gas en die druk, ten einde druppeldigtheid en -grootte in die gedeponeerde lagie te minimeer.

\section{Pulsed laser deposition of platinum-based alloys}

An alternative to Ni-based alloys, with greater hardness and better oxidation and corrosion resistance, are Pt-based alloys. Since the Ni alloys used in jet engine turbines are already used at $90 \%$ of their melting point, the search for an alternative is of the utmost importance. Pulsed laser deposition (PLD) provides a technique for growing thin films of Pt-based alloys. 


\title{
'n Model vir inligtingsekerheidsbestuur gebaseer op wêreld- standaarde
}

\author{
M.M. LeSSING \\ Akademie vir Inligtingstegnologie, Universiteit van Johannesburg, \\ Posbus 923, Ferndale 2160 \\ marthie.lessing@gmail.com
}

Tans is daar geen omvattende model vir inligtingsekerheidsbestuur wat aan al die erkende wêreldstandaarde voldoen nie. Die gevolg is dat organisasies nie noodwendig inligtingsekerheidsbestuur optimaal implementeer of benut nie. Dit gebeur soms dat organisasies al hul hulpbronne op 'n spesifieke gedeelte van inligtingsekerheidsbestuur spandeer, maar ander dele totaal weglaat. Sekere gedeeltes is dus ten volle gedek, terwyl ander gedeeltes geen dekking geniet nie, en dus 'n hoë sekuriteitsrisiko kan inhou. Ten spyte van só 'n organisasie se gedeeltelike inligtingsekerheidsbestuurinsette, sal die organisasie nie die inligting tot die beste van sy vermoë kan bestuur en beskerm nie, en sodoende word 'n geleentheid vir kwaadwilligheid geskep.

Deur wêreldstandaarde en ander toepaslike dokumente van die inligtingsekerheids-, inligtingtegnologie- en korporatiewe bestuursdissiplines te ontleed, ontstaan die moontlikheid om 'n enkele omvattende model te skep. Met behulp van só 'n model kan enige organisasie, ongeag die grootte of korporatiewe kultuur daarvan, tot volle inligtingsekerheidsbestuur gelei word.

Die model wat voorgestel word, bevat negentien kritieke komponente wat aan sewe verskillende wêreldstandaarde ontleen is. Deur 'n breedvoerige studie en ontleding van die aard en doel van die implementering van inligtingsekerheidsbestuur, kon die kritieke komponente (oftewel, die drywers vir die stelsel) geïdentifiseer word. Die studie het ook beoog om die implementering van wêreldstandaarde op alle terreine te bevorder, en die idee te versterk dat 'n organisasie wat nie aandag aan inligtingsekerheidsbestuur gee nie, die weg vir moontlike ondergang baan. Die wêreldstandaardmodel vir inligtingsekerheidsbestuur het dit verder ten doel gehad om die beste, mees toepaslike gedeeltes uit die gekose wêreldstandaarde te neem, vir die samestelling van 'n geskikte model wat in alle situasies geïmplementeer kan word.

Die dokumente wat as die basis vir dié studie gebruik is, is COBIT en ITIL (ontleen aan die inligtingtegnologiebestuursdissipline), die King II Verslag, OECD en die Sarbanes-Oxley Wet (ontleen aan die korporatiewebestuursdissipline), ISO 17799 en die Standard of Good Practice for Information Security (ontleen aan die inligtingsekerheidsbestuursdissipline). Die model wat uit die studie voortspruit, dek derhalwe die volle spektrum van al drie hierdie dissiplines, aangesien die toepaslike wêreldstandaardriglyne en regsdokumente daarin geïnkorporeer is.

'n In-diepte-ondersoek van die oorsprong en struktuur van die sewe brondokumente lei tot 'n volledige motivering vir die insluiting van die verskillende komponente in die model. Aanvanklik is 31 komponente geïdentifiseer, maar na 'n volledige ontleding van die komponente, is ' $n$ finale wêreldstandaard gebaseerde model ontwikkel wat uit slegs 19 uitgebreide komponente bestaan.

Die implementering van wêreldstandaarde hou verskeie addisionele voordele vir organisasies in. Nie alleen kan organisasies uit ander se foute leer nie, maar daar is ook sekere gebruike wat reeds ten volle beproef is. Organisasies wat hierdie wêreldstandaard gebaseerde inligtingsekerheidsbestuursmodel implementeer, kan dus verseker wees van beproefde inligtingsekerheidsmaatreëls wat alle moontlike aspekte van die organisasiestruktuur dek.

Bykomend tot die studie, is ' $n$ interaktiewe hulpgids opgestel om die inligtingsekerheidsbeampte te help om die model so doelmatig moontlik binne die raamwerk van 'n organisasie te implementeer. 


\title{
A model for information security management based on world standards
}

To ensure successful information security management, organisations should follow the guidelines set out in best practice documents. By combining relevant sections from information security management, information technology management and corporate governance disciplines, a single, comprehensive model, which is based on world standards, was created to guide organisations to a comprehensive approach to information security management.

\section{Identifikasie en hantering van konseptuele probleme by studente in eerstejaarschemie}

\author{
A.F. Marais \\ Departement Chemie, Tshwane Universiteit van Tegnologie, \\ Privaatsak X680, Pretoria 0001 \\ maraisf@tut.ac.za
}

Ongelykhede van die vorige onderwysstelsel word voortgesit in swak toegeruste skole en onvolwaardig opgeleide onderwysers, veral in die wiskundige en wetenskaplike rigtings. As gevolg hiervan betree swak voorbereide studente die tersiêre vlak van opleiding by universiteite. Die eindresultaat is onbevredigende slaagsyfers vir wiskunde en die natuurwetenskappe onder eerstejaarstudente.

In hierdie studie word die konseptuele probleme van 32 studente (die eksperimentele groep) ondersoek. Hierdie studente is aanvaar en geregistreer vir 'n grondslagprogram wat toelating tot eerstejaarstudie in analitiese chemie by die Tshwane Universiteit van Tegnologie (TUT) voorafgaan.

$\mathrm{Na}$ vasstelling van die probleme, is 'n rekenaargesteunde ingryping wat gebruik maak van grafiese animasie, addisionele vrae en selftoetsmaatreëls, opgestel om die geïdentifiseerde probleme te oorbrug. Die ingryping is eers aan die eweknie-goedkeuring van mededosente onderwerp en toe aan die eksperimentele groep voorgehou. 'n Rekenaargesteunde ingryping is doelbewus gekies met die oog op beter benutting van die spesifieke hulpbron in die toekoms en weens die feit dat die nuutste tegnologie vanselfsprekend by 'n universiteit van tegnologie tuishoort en weens die vermoede dat rekenaars en aanverwante tegnologie moontlik nie optimaal by die Department Chemie aan die TUT aangewend word nie.

Die studente in die eksperimentele groep wat die grondslagprogram geslaag het en tans besig is met eerstejaarschemie, is weer getoets om die sukses van die ingryping te bepaal. Daar is ook gepoog om die houding van die studente met betrekking tot die rekenaargesteunde lesingmetode vas te stel. Voorlopige bevindinge en moontlike verklarings word in hierdie voorlegging bespreek.

\section{Identifying and overcoming conceptual problems of first-year chemistry students}

The conceptual problems of first-year chemistry students were investigated using the Journal of Chemical Education (JCE) chemical concepts inventory. Once the problems had been identified, a computer-based intervention was developed in order to overcome them. The intervention was first peer-reviewed by all the first-year chemistry lecturers at the Tshwane University of Technology before it was implemented. 


\title{
Metabolomiese profielbepaling van Pelargonium sidoides DC en $P$. reniforme CURT
}

\author{
J.E. Maree*, A.M. Viljoen en M. Manley \\ Departement van Farmaseutiese Wetenskappe, Tshwane Universiteit van Tegnologie, Privaatsak \\ X680, Pretoria, 0001. \\ *mareeje1@tut.ac.za
}

Pelargonium sidoides en $P$. reniforme is inheemse plante van Suid-Afrika met 'n sentrum van diversiteit in die Oos-Kaapprovinsie. Die twee spesies word deur Suid-Afrikaanse tradisionele genesers as baie belangrike medisinale plante geag. Verskillende etniese groepe gebruik al vir honderde jare lank die wortels vir die behandeling van hoes, boonste lugwegirritasies en maagdermtoestande. 'n Etanoliese ekstraksie van P. Sidoides-wortels, bekend as Umckaloabo ${ }^{\circledR}$, word tans baie suksesvol in Duitsland bemark, met verkope wat met meer as $700 \%$ gegroei het. Ten spyte van die kommersiële belangstelling in die twee plantspesies, is daar relatief min studies gedoen om die totale fitochemiese variasie van die natuurlike populasies te bepaal. Die beskikbare literatuur handhaaf ook verskillende menings oor watter een van die spesies tradisioneel vir sekere kwale gebruik is.

In hierdie projek is die totale fenoliese inhoud en fitochemiese variasie binne en tussen populasies van P.sidoides en $P$. reniforme bepaal. Fitochemiese profiele van $P$. sidoides en $P$. reniforme is saamgestel en met mekaar vergelyk. 'n Eenvoudige en verfynde prosedure vir die validasie van onverwerkte plantmateriaal word voorgestel. Plantmonsters is in verskillende areas in die OosKaapprovinsie in Suid-Afrika versamel. 'n Mengsel van metanol en dichlorometaan (1:1) is as ekstraksievloeistof vir die wortels gebruik, waarna analises gedoen is om die fitochemiese inhoud te bepaal. Die analises van hierdie ekstraksies is deur middel van infrarooispektroskopie (NIRS) en dunlaagkromatografie (TLC) uitgevoer.

Die NIRS-data het aangetoon dat daar'n definitiewe fitochemiese verskil tussen $P$. sidoides en $P$. reniforme is. Daar is bevind dat daar meer fitochemiese variasie in dieselfde populasie as tussen populasies is. Intra- en interspesifieke fitochemiese vingerafdrukvariasie van die spesies is bepaal deur die data van die TLC-analises vir die verskillende geografiese areas en spesies te vergelyk. Chemiese komponente is geïsoleer en as merkerkomponente tydends TLC-analise gebruik. Die invloed van die intra- en interspesifieke fitochemiese variasie van die spesies is vasgestel deur die plantmonsters se minimum inhiberende konsentrasies (MIC) te bepaal. Drie bakterieë, Staphylococcus aureus (ATTC 6538), Klebsiella pneumoniae (ATTC 13883) en Mycobacterium smegmatis, en twee fungi, Candida albicans (ATTC 10231) en Cryptococcus neoformans (ATTC 90112), is gebruik om die MIC te bepaal. Die resultate het aangetoon dat die minimum inhiberende konsentrasies van 'n plantspesie varieer, afhangende van die monster se geografiese oorsprong. Daar was verder variasie in die MIC-waardes tussen spesies en beide spesies het min aktiwiteit teen Candida albicans getoon.

\section{Metabolomic profiling of Pelargonium sidoides DC en $P$. reniforme CURT}

Pelargonium sidoides and $P$. reniforme are indigenous medicinal plants that are widely used in South Africa. Few studies have been conducted to document the full phytochemical variation in and between natural populations. In this study, root extracts were analysed by means of infrared spectroscopy (NIRS), thin-layer chromatography (TLC) and minimum inhibiting concentrations (MIC) to determine their variation in terms of phytoconstituents. 


\title{
Die problematiek van die begrip "oneindigheid" in wiskunde- onderwys
}

\author{
R. Mathlener \\ Departement Verdere Onderwysersopleiding, Universiteit van Suid-Afrika, \\ Posbus 392, Unisa 0003 \\ rmathlener@telkomsa.net
}

Oneindigheid het die mensdom nog altyd gefassineer. 'n Studie van die filosofies-historiese fondamente van oneindigheid toon die problematiese ontwikkeling daarvan. Griekse filosowe het reeds die term "oneindigheid" gebruik. Zeno van Elea het geglo dat beweging slegs 'n illusie is en het verskeie paradokse uiteengesit om dit te illustreer. Hy het in sy eerste twee paradokse (die digotomie en die Achilles) aangetoon dat logiese absurditeite ontstaan as gevolg van die begrip "oneindige verdeelbaarheid" van ruimte en tyd. Aristoteles het onderskei tussen die potensieel en wesenlik oneindige, maar het laasgenoemde verwerp. Cantor het die probleem van die wesenlik oneindige tydens die $19^{\text {de }}$ eeu opgelos. ${ }^{1}$ Hy het 'n versameling as oneindig gedefinieer indien dit ' $n$ een-tot-een relasie met 'n ware deelversameling van homself het.

Oneindigheid dui op iets onbeperk, oneindig en grensloos. ${ }^{2}$ Bernays (1964) beskryf twee begrippe van oneindigheid ${ }^{3}-(1)$ potensiële oneindigheid: die oneindigheid van 'n proses wat nooit ophou nie, en (2) wesenlike oneindigheid: 'n statiese en voltooide oneindigheid wat as voorwerp beskou kan word. Die historiese ontwikkeling van die begrip "oneindigheid" het met vele probleme en teenstrydighede gepaard gegaan. Die mens se intuïsie omtrent oneindigheid is inherent teenstrydig, aangesien ons logiese skemas van nature aangepas is vir eindigende voorwerpe en gebeure. ${ }^{4}$ Vir die menslike verstand is dit moeilik - selfs onmoontlik - om die wesenlik oneindige te begryp, soos die aantal punte op 'n lynsegment, of die werklike bestaan van die oneindigheid van reële getalle as 'n gegewe. ${ }^{1}$

Sodra 'n mens te doen kry met die wesenlik oneindige, ontstaan daar teenstrydighede. Bezuidenhout (2001) sê dat, alhoewel eerstejaarstudente somtyds limiete kan bereken en ook kan differensieer en integreer, hulle nie die verband tussen fundamentele konsepte (bv. "limiet", "kontinuïteit", "afgeleide" en "integrale") in differensiaalrekene begryp nie. ${ }^{5}$ Die meeste studente visualiseer 'n limiet as 'n dinamiese proses en nié as 'n numeriese waarde nie (Tall 1980). ${ }^{6}$ Tall sê dat individue op verskillende tye klaarblyklik teenstrydige intuïtiewe gedagtes kan hê, sonder om bewus te wees van die kognitiewe konflik.

In wiskunde-onderwys behoort studente se intuïtiewe denke omtrent die oneindige geïntegreer te word met weldeurdagte, sinvolle metodes vir die onderrig van konsepte soos "irrasionale getalle", "limiet" en "kontinuïteit". Die onderrig en leer van die begrip "oneindigheid" blyk ook problematies te wees. Leerders en studente se intuïtiewe begrip van die wesenlik (voltooide) en potensieel (onvoltooide) oneindige is deur middel van vraelyste en ongestruktureerde onderhoude in ' $n$ kwalitatiewe benadering ondersoek. Daardeur is 'n diepgaande insig in studente se begrip van oneindigheid verkry. Die meeste studente se intuïtiewe definisie van oneindigheid dui op potensiële oneindigheid. Studente fokus primêr op oneindigheid as 'n proses - iets wat onbepaald voortgaan. Hul voorbeelde uit die alledaagse lewe is teenstrydig met hul definisies.

\section{Verwysings}

1. Fischbein, E. 2002. Tacit models and infinity. Educational Studies in Mathematics, 48:309-329.

2. Hilbert, D. 1925. On the infinite. In P Benacerraf \& H Putnam: Philosophy of mathematics: Selected readings 1964. Oxford: Basil Blackwell, pp. 134-151. 
3. Bernays, P. 1964. On Platonism in mathematics. In P Benacerraf \& H Putnam: Philosophy of mathematics: Selected readings. Oxford: Basil Blackwell, pp. 274-286.

4. Monaghan, J. 2001. Young people's ideas of infinity. Educational Studies in Mathematics, 48:239-257.

5. Bezuidenhout, J. 2001. Limits and continuity: some conceptions of first-year students. International Journal of Mathematical Education in Science and Technology, 32(4):487-500.

6. Tall, D 1980. Mathematical intuition, with special reference to limiting processes. Proceedings of the Fourth International Conference for the Psychology of Mathematics Education. Berkeley, pp. 170-176.

\title{
The problematic nature of the concept of "infinity" in mathematics education
}

It is evident from the history and philosophy of mathematics that understanding the concept "infinity" is a source of great difficulty and contradictions. Infinity may be potential and actual. This study shows that students intuitively experience infinity as dynamic processes, but the actual infinite is difficult to verbalise.

\section{Luminessensie-eienskappe van $\mathrm{SrAl}_{2} \mathrm{O}_{4}: \mathrm{Eu}^{2+}, \mathrm{Dy}^{3+}$ fosfor}

\author{
S. Nieuwoudt ${ }^{* 1}$, J.J. Terblans ${ }^{1}$, J. Ngaruiya ${ }^{1}$, O.M. Ntwaeaborwa ${ }^{1}$, \\ E. Coetsee ${ }^{1}$, K.T. Hillie ${ }^{2}$ en H.C. Swart ${ }^{1}$ \\ ${ }^{1}$ Departement Fisika, Universiteit van die Vrystaat, Posbus 339, Bloemfontein 9301 \\ ${ }^{2}$ WNNR-NML, Posbus 395, Pretoria 0001 \\ *nieuwoudts.sci@ufs.ac.za
}

Padinfrastruktuurmateriale soos padtekens, padmerke, en reflekterende toestelle soos katoë op die pad wat tans in gebruik is, is afhanklik van 'n eksterne ligbron en dus indirek afhanklik van elektrisiteit of 'n elektriese kragbron. Hierdie tekens reflekteer die lig wat in hulle rigting geskyn word. Vir gevalle waar daar geen eksterne bron van lig is nie, soos byvoorbeeld buite-distrikte, is die sigbaarheid van hierdie tekens baie swak. 'n Alternatiewe metode om hierdie padinfrastruktuurmateriale te belig, word benodig om hierdie struikelblok te oorkom.

$\mathrm{SrAl}_{2} \mathrm{O}_{4}: \mathrm{Eu}^{2+}, \mathrm{Dy}^{+}{ }^{+}$fosfor is 'n groen fosfor wat deur ultravioletlig (UV) opgewek kan word. Die son se UV-strale kan dus as natuurlike energiebron vir die opwekking van hierdie liggewende poeier dien. Na opwekking, gee hierdie fosfor 'n heldergroen lig met 'n golflengte van $514 \mathrm{~nm}$ af. Omdat die relatiewe sensitiwiteit van die menslike oog vir elektromagnetiese golflengtes 'n maksimum in die geel-groen golflengte-gebied bereik, sal die lig wat deur hierdie fosfor afgegee word, beter raakgesien word as ' $n$ ander kleur lig. Uit die literatuur is dit duidelik dat $\mathrm{SrAl}_{2} \mathrm{O}_{4}: \mathrm{Eu}^{2+}, \mathrm{Dy}^{3+}$ fosfor oor uitstaande eienskappe beskik, soos 'n lang na-gloei-leeftyd van tussen 4 en 10 ure, 'n hoë helderheidsintensiteit, hoë kwantum-effektiwiteit, uitstekende chemiese stabiliteit en gebruiksveiligheid.

$\mathrm{SrAl}_{2} \mathrm{O}_{4}: \mathrm{Eu}^{2+}, \mathrm{Dy}^{3+}$ se luminessensie-eienskappe is van naderby bestudeer. Auger elektronspektroskopie (AES), skandeerelektronmikroskopie (SEM), energiedispersiespektroskopie (EDS), $\mathrm{x}$ straaldiffraksie (XRD), katode- (CL) en fotoluminessensie (PL) is gebruik om die fosfor te karakteriseer. Gebaseer op die eksperimentele resultate en 'n bestaande meganisme wat in die literatuur beskryf word, word 'n nuwe meganisme as moontlike verklaring vir die lang na-gloei-leeftyd van hierdie fosfor aan die hand gedoen en bespreek.

\section{Luminescent properties of $\mathrm{SrAl}_{2} \mathrm{O}_{4}: \mathrm{Eu}^{2+}, \mathrm{Dy}^{3+}$ phosphor}

Strontium aluminate is a phosphor which is ideal for warning light/reflective applications in the road and construction industry (eg in "cat eyes" on roads) because of its brightness and long persistent 
glow time. The luminescent properties of $\mathrm{SrAl}_{2} \mathrm{O}_{4}: \mathrm{Eu}^{2+}, \mathrm{Dy}^{3+}$ phosphor were studied using Auger electron spectroscopy, scanning electron microscopy, energy dispersive spectroscopy, X-ray diffraction, and cathode- and photoluminescence.

\title{
Produkontwikkeling vir speelterapie: die stimulasie van kinders met leerprobleme deur die gebruik van hulle sintuie
}

\author{
Y. OLIVIER \\ Skool vir Ontwerptegnologie en Visuele Kuns, Sentrale Universiteit van Tegnologie, \\ Privaatsak X20539, Bloemfontein 9300 \\ yolandi.olivier@vodamail.co.za
}

Verskeie multidissiplinêre benaderings kan aangewend word in die behandeling van kinders met leerprobleme. 'n Multidissiplinêre benadering sluit speelterapie, remediërende terapie, fisioterapie, sowel as die toediening van 'n stimulant in.

Speelterapie kan in 'n kind met leerprobleme die vermoë ontsluit om herinneringe en belewenisse in sy of haar lewe te herleef, met ander te deel, en te begryp. Die Sensoriese Profieltoets (Sensory Profile Test) mag 'n nuttige hulpmiddel wees in die vasstelling en/of bevestiging van die hoofpunte in die diagnose van Aandagtekort-hiperaktiwiteit-versteuring (Attention deficit hyperactivity disorder [ADHD]) in kinders. Navorsing het getoon dat kinders geen probleme ondervind om elk van die vyf sinsorgane aan ' $n$ sintuiglike funksie te verbind nie. Waar' $n$ kind in staat is om 'n betrokke sinsorgaan te identifiseer, is dit egter nie 'n bewys daarvan dat daardie kind ook die betrokke sinsorgaan se funksie sal begryp nie (Weinberger \& Bushnell 1994). Roger et al. (2003) het nietemin aangedui dat indien 'n kind probleme ondervind om elk van die vyf sinsorgane met 'n sintuiglike funksie te verbind, dit 'n aanduiding van 'n onderliggende leerprobleem mag wees.

Die doel van hierdie studie was om vas te stel of daar 'n verskil bestaan tussen kinders met leerprobleme en kinders sonder leerprobleme, met betrekking tot hul differensiële sensitiwiteit. Twintig kinders wat met leerprobleme gediagnoseer is en twintig kinders sonder leerprobleme het aan die studie deelgeneem. Hulle moes 'n reeks handelinge uitvoer waartydens interaksie met 'n aantal voorwerpe van verskillende kleure, verskillende klank- en reukstimuli, asook 'n dubbeleaanrakingstimulus plaasgevind het. Dié ondersoek het bevind dat kinders met leerprobleme dit moeiliker vind om hul sinsorgane en gepaardgaande sintuiglike funksies te identifiseer, as kinders sonder leerprobleme. Op grond van hierdie waarneming postuleer hierdie studie dat dit moontlik behoort te wees om 'n kind met leerprobleme vroeër te identifiseer indien sensoriese stimulante met mediums wat tydens speelterapie aangewend word, geïntegreer sou word.

Insigte wat uit hierdie studie verkry is, en afleidings wat uit die bevindinge van ander navorsers gemaak is, het die rigting aangedui vir die ontwikkeling van produkte wat sensoriese stimulante insluit, en in speelterapie aangewend kan word.

Hierdie studie bied ook riglyne vir die ontwerp en ontwikkeling van speelterapie-produkte wat sensoriese stimulante insluit. Dit dra ook tot moontlike verdere navorsing en ontwikkeling op dié gebied by.

\section{Product development for play therapy: stimulating children with learning disabilities through the use of their own senses}

The aim of this study was to determine whether there is a difference between children with learning disabilities and those without learning disabilities (LD) in terms of identifying their sensory organs

Suid-Afrikaanse Tydskrif vir Natuurwetenskap en Tegnologie, Jaargang 27 No. 2: Junie 2008 
and in terms of their differential sensitivity. The study found that children with LD have more difficulty in identifying their senses and the functions of the senses than children without LD. Children can benefit if sensory stimulants are integrated into play therapy mediums.

\title{
Die sosiale verantwoordelikheid van wetenskaplikes: wat dink ons studente?
}

\author{
D. RöHM \\ Departement Chemie, Universiteit van Suid-Afrika, Posbus 392, Unisa 0003 \\ rohmd@unisa.ac.za
}

Die toenemende impak wat die wetenskap en tegnologie op die mens en sy omgewing uitoefen, vereis dat wetenskaplikes sosiale verantwoordelikhede moet aanvaar. Opkomende jong wetenskaplikes moet dus die nodige kennis en vaardighede verwerf om aan hierdie vereiste in hulle loopbane te voldoen. Vir sodanige opvoeding is dit egter nodig om te weet wat die student se beskouings en houdings op dié gebied is. Gevolglik is 'n navorsingsprojek aan die Universiteit van Suid-Afrika onderneem om vas te stel wat wetenskapstudente se beskouings oor sosiale verantwoordelikheid is.

Die ontwikkeling van die navorsingsinstrument het deurgaans op die menings van studente berus. Inligting wat uit onderhoude verkry is, het as vertrekpunt gedien. Hiervolgens is 'n oopkeusevraelys geformuleer, waarvan die resultate uiteindelik in 'n meerkeuse-vraelys vervat is. Die analise dek 'n breë spektrum van faktore wat sosiaal verantwoordelike wetenskapsbeoefening bepaal en dui ook die gepaardgaande opinies van die respondente aan.

Sosiale verantwoordelikheid in die wetenskapspraktyk word bepaal deur wetenskaplike vryheid, navorsingsdoelwitte, en die besef van die mag van kennis. Die langtermyn- asook ongekontroleerde gevolge van tegnologiese innoverings is ondersoek. Wetenskaplike vooruitgang in Afrika en die rol van die vrou is hoofsaaklik as 'n kwessie van gelykheid gesien. Met hierdie benadering kan nuwe projekte geïnisieer en tradisionele kennis toegepas word. Op individuele vlak speel persoonlike waardes, die nakoming van die wetenskapsetos, sowel as 'n verbintenis om die publiek te beskerm en in te lig 'n belangike rol.

Sensitiewe raakvlakke bestaan tussen die wetenskap, die tegnologie en die samelewing. Daarom behoort die morele implikasies van navorsing, verskille in waardesisteme, samewerking met gemeenskappe en die oordrag van wetenskaplike kennis in aanmerking geneem te word. Hiermee gaan gemeenskaplike besluitneming en die gevolglike gemeenskaplike verantwoordelikheid vir die impak van die gebruik van tegnologie gepaard.

Sosiale verantwoordelikheid op opvoedkundige gebied vereis onderrig oor die invloed van die wetenskap op die omgewing, sowel as die samelewing. Daar is 'n behoefte aan meer toegepaste kennis, asook kennis oor etiese, filosofiese en maatskaplike temas wat by 'n Afrika-model aansluit. Studente was gretig om opvoedkundig in hulle gemeenskappe betrokke te raak, en het 'n behoefte aan navolgenswaardige rolmodelle.

Die hoofredes vir bogenoemde uitgangspunte was deurgaans gerig op die vooruitgang en beskerming van gemeenskappe, asook hul reg op wetenskaplike inligting. Die publiek se betrokkenheid in besluitneming, die verantwoordelike gebruik van tegnologie, en vertroue in wetenskaplikes moet bevorder word.

Wetenskaplikes moet egter op hul beurt verseker wees van institusionele en wetlike ondersteuning om sosiaal verantwoordelike besluite te kan neem. Die instelling van professionele gedragskodes kan bydra om wetenskaplikes te onderskraag en te monitor. 


\section{The social responsibility of scientists: what do our students think?}

A study of the views of science students on the social responsibility of scientists deals with aspects pertaining to the scientific enterprise, the personal role of scientists, the science-technology-society interface and education. Science in Africa, the role of women, communication, decision making and responsibility for the consequences of technological innovations are highlighted.

\section{Die gebruik van satellietbeelde vir die waarneming van plantegroeiverandering: die impak van olifante onder verskillende bestuurstrategië̈}

\section{C.A. Simms}

Skool vir Omgewingswetenskappe, Universiteit van Suid-Afrika, Posbus 392, Unisa 0003 csimms@webmail.co.za

Die getalle van Afrika-olifante (Loxodonta africana) is besig om oor groot gedeeltes van Afrika af te neem. Olifante word onwettig vir vleis en ivoor gejag, en baie van hul historiese weidingsgebiede is onbereikbaar as gevolg van toenemende menslike ontwikkeling. Met minder as sewehonderdduisend olifante oor in die natuur, is die bewaring van die oorblywende olifante van groot belang.

Olifante kan egter baie skade aan plantegroei aanrig, en in klein, afgekampte gebiede kan onomkeerbare verandering aangerig word. Sulke skade kan die biodiversiteit van die gebied verlaag en ander bedreigde spesies benadeel. Die olifantprobleem, soos dit genoem word, behels dus die soeke na 'n balans tussen maksimum olifantgetalle en minimum ekologiese skade.

Die kwessie word verder gekompliseer deur verskille in die bewaringsbeleide van die verskillende beskermingsgebiede. Party reservate fokus op die bewaring van biodiversiteit, terwyl ander se fokus op toerisme en die "Groot Vyf" is. Dit lei tot verskillende bewaringstrategieë, wat dan verskillende bewaringsresultate tot gevolg het. Die bewaringstrategieë wat in hierdie studie ondersoek word, is die verskaffing van mensgemaakte waterpunte, die beheer van die getalle grootwildsoorte (insluitend olifante), asook die beheer van brande. Mensgemaakte waterpunte konsentreer wild in gebiede wat voorheen vir seisoenale beweiding benut sou word, en het dus 'n groot impak op die plantegroei in die omgewing van waterpunte. Grootwildsoorte soos kameelperde en koedoes kan ook die plantegroei beïnvloed, alhoewel hulle invloed nie so opmerklik soos dié van olifante is nie. Vuur het ook 'n impak op die verspreiding en samestelling van plantegroei en moet dus ook gemonitor word.

Tembe Elephant Park in KwaZulu-Natal en die Welgevonden Privaat Natuurreservaat in die Limpopo-provinsie van Suid Afrika, is as studiegebiede gekies. Die twee reservate is omtrent ewe groot en het ongeveer dieselfde aantal olifante. Hulle verskil egter ten opsige van hul bewaringsfokus. Tembe Elephant Park huisves ook die hoogs bedreigde soenie (Neotragus moschatus) en het 'n endemiese sand-woud-ekosisteem. Daar is een toeristekamp in Tembe; die paaie is slegs per vierwielaangedrewe voertuig begaanbaar; en net een mensgemaakte waterpunt is opgerig. Aan die ander kant is daar omtrent sestig toeristekampe in die Welgevonden Privaat Natuurreservaat, met 'n groot aantal mensgemaakte waterpunte.

Die impak van olifante op die plantegroei van die twee bewaringsgebiede sal op grond van veranderings in satellietwaarnemings vasgestel word. LANSAT- en SPOT-satellietbeelde sal oor 'n tydperk van 15 jaar gebruik word om veranderings in die plantegroei te volg. Die effek van die verskillende bestuursplanne op die ruimtelike verspreiding van die gebiede wat deur olifante beskadig is, sal dan geëvalueer word. 


\title{
The use of satellite imagery to detect changes in vegetation: visualising elephant impact under different management strategies
}

Large elephant populations can cause irrevocable change to vegetation and be disadvantageous to the biodiversity of other life forms in the area. Different conservation policies in respect of protected areas result in different management strategies and conservation outcomes. The impact of elephants in the Tembe Elephant Park in KwaZulu-Natal and the Welgevonden Private Game Reserve in the Limpopo province will be evaluated by tracking changes to the vegetation with the aid of satellite imagery over a period of 15 years.

\section{'n Rangorde-algoritme vir akademiese tydskrifte}

\author{
M.C.STRYdom \\ Departement Besluitkunde, Universiteit van Suid-Afrika, Posbus 392, Unisa 0003 \\ strydmc@unisa.ac.za
}

Daar bestaan 'n behoefte aan 'n objektiewe maatstaf om die gehalte van akademiese publikasies te bepaal en te vergelyk.

Daar bestaan verskillende maatstawwe om die gewildheid, impak of kwaliteit van tydskrifte te meet. Die metodes wat in hierdie meting gebruik word, is nie altyd deursigtig nie. Dikwels word die aantal verwysings as die basis vir die berekeninge gebruik. Die uitgewer ISI Thomson publiseer byvoorbeeld 'n sogenaamde "impakfaktor". Dit gee 'n aanduiding van die frekwensie van verwysings na artikels in 'n tydskrif. Daar word geen onderskeid getref tussen die verwysings na artikels in bekende tydskrifte en dié na artikels in onbekende tydskrifte nie.

Hierdie studie kyk na metodes om die invloed van tydskrifte uit verwysingsdata te bereken. 'n Iteratiewe proses, wat 'n gewig aan die bron van die verwysing toeken, is gebruik.

Daar bestaan baie ooreenkomste tussen die verbindingstruktuur van die Internet en die verwysings tussen akademiese tydskrifte. Die soekenjin Google skryf hul sukses toe aan die PageRank-algoritme waarmee die rangorde van webblaaie bepaal word. Die PageRank-algoritme gebruik die verbindings tussen webblaaie om iteratief 'n gewig vir elke blad te bereken.

Nadat die faktore wat die kwaliteit en belangrikheid van navorsing bepaal met spesialisnavorsers bespreek is, is daar besluit om 'n maatstaf wat die "Invloedfaktor" genoem is, te bereken. Die Invloedfaktor, wat met 'n variasie van die PageRank-algoritme bereken word, is 'n maatstaf van die reaksie wat deur 'n publikasie gegenereer is. 'n Tydskrif se Invloedfaktor is gebaseer op die aantal navorsers, en die belangrikheid van die navorsers wat na artikels in die tydskrif verwys het.

In hierdie studie is klein, kunsmatige netwerke bestudeer om die invloed van die verwysingstruktuur op die gewig van bronne te bepaal. Daarna is die algoritme op netwerke van data uit die Citeseer-databasis en ISI Thomson se databasis getoets.

Die metode wat die persepsie van navorsers (empiries bepaal) die beste weergee is as volg:

- Ken arbitrêr 'n gewig aan elke tydskrif toe en bereken nuwe waardes vir die Invloedfaktor.

- Die huidige Invloedfaktor word dan oorgedra na alle tydskrifte wat verwysings van 'n spesifieke tydskrif ontvang. Al die waardes word opgetel en met 'n dempingsfaktor vermenigvuldig om 'n nuwe gewig vir elke tydskrif te gee.

- Onderskeid word getref tussen selfverwysings (verwysings na artikels wat in dieselfde tydskrif verskyn het) en ander (eksterne) verwysings. 
- Kwadratiese normalisering word toegepas.

- Die proses word herhaal totdat dit konvergeer.

Die waardes van die parameters is empiries bepaal. Selfverwysings het ongeveer ' $n$ derde van die gewig van verwysings van ander bronne gehad. Die spesialisnavorsers wat genader is, het gevoel dat selfverwysings van 'n klein groep kan kom en verwysings van ander bronne op groter invloed van die publikasie dui. Die dempingsfaktor het dieselfde waarde as dié wat Google gebruik.

Olson [Julie 2005] het 'n empiriese studie gedoen waarin 25 akademici genader is om hul persepsie van die gehalte van Operasionele Navorsing- en Bestuurswetenskaptydskrifte te bepaal. Die tydskrifte is daarvolgens in 'n rangorde geplaas. Die rangorde wat deur die Invloedfaktor toegeken is, stem grootliks met dié rangorde ooreen.

Daar bestaan ook 'n goeie korrelasie tussen die rangorde wat deur die Invloedfaktor toegeken word en dié wat deur 'n paar spesialisnavorsers in hul onderskeie navorsingsgebiede toegeken word.

\section{A ranking algorithm for academic journals}

In this research an influence factor was calculated based on the PageRank algorithm of the Google search engine, in order to determine the ranking of academic journals. This iterative algorithm takes the number and importance of citations into account to determine the reaction generated by a publication.

\section{Die elektriese resonantpunte van marmer}

\section{A.J. Swart* EN H.C. vZ PienaAR}

Fakulteit Ingenieurswese en Tegnologie, Vaal Universiteit van Tegnologie, Privaatsak X021, Vanderbijlpark 1900

*jamess@vut.ac.za

\section{Inleiding}

Die elektriese eienskappe van rotse kan gebruik word in mineraalnavorsing, planetêre peilings en mineraalveredeling. Eienskappe soos impedansie, resonantpunte en permitiwiteit is veral belangrik in die diëlektriese verhitting van materiale. In dié voorlegging word die bepaling van die elektriese eienskappe (resonantpunte) van twee soorte marmer bespreek.

Marmer is alombekend as 'n pragtige, gepoleerde materiaal wat vir versieringsdoeleindes aangewend word. Dit is 'n metamorfiese karbonaatrots wat hoofsaaklik uit kalsiet of dolomiet bestaan. Hoë temperature het 'n groot invloed op die geologiese formasie van marmer uitgeoefen, en veroorsaak dat kalsiet geherkristalliseer het.

\section{Navorsingsopstelling}

Die elektriese eienskappe van rotse, wat marmer insluit, kan met behulp van spesifieke toetsapparate bepaal word. Die toetsapparate wat gebruik kan word sluit die vektorimpedansiemeter en die vektorvoltmeter in. In hierdie navorsing is 'n vektorvoltmeter gebruik om die impedansie (grootte $|\mathrm{Z}|$ en fasehoek $\grave{e}$ ) van 'n diëlektriese materiaal - in hierdie geval marmer - by verskillende frekwensies te 
meet. Die marmermonster is in die vorm van 'n reghoek met afmetings 35 x 19 x 4 mm gesny, en is deur middel van die parallelplaatkapasitormetode aan die vektorvoltmeter gekoppel.

\section{Die parallelplaatkapasitormetode om die resonantpunte van marmer te bepaal}

Die metings is in 'n Faraday-hok geneem om enige radiofrekwensie (RF)-steurnisse uit te sluit. 'n Vektorvoltmeter (HP 8508A) en 'n RF-seingenerator (Marconi 2024) is gebruik om die resonantpunte van die marmermonster te bepaal. Koperplate is deur middel van 'n hout klembeuel aan albei kante van die monster gekoppel. Die plate is toe deur middel van 'n kragverdeler en koaksiale kabels aan die toetsapparate gekoppel. Die impedansie (Z) van die ekpserimentele monster is as volg:

$$
Z=R \pm j\left(\omega L-\frac{1}{\omega C}\right) \quad \text { ohm }
$$

Waar $R \equiv$ die weerstand van die diëlektriese materiaal in ohm

$\omega \equiv$ die hoekfrekwensie in radiale

$L \equiv$ die induktansie in henry

$C \equiv$ die kapasitansie in farad

Elektriese resonansie vind plaas by 'n frekwensie $\left(f_{o}\right)$ waar die impedansie 'n suiwer weerstand is met geen hoek nie:

$$
Z=R
$$

By resonansie is

$$
\begin{aligned}
& \omega L=\frac{1}{\omega C} \\
& \omega^{2}=\frac{1}{L C} \\
& f_{o}=\frac{1}{2 \times \pi \times \sqrt{L C}}
\end{aligned}
$$

Daar is gevind dat die marmermonster so dun as moontlik gesny moet word om wanaanpassings te verhoed, om energieverlies te verminder en om swerfkapasitansies en -induktansies teen te werk. Twee verskillende monsters, tremoliet met kalsiet en daarna dolomiet, is tydens die eksperiment gebruik, oor 'n frekwensiespeling van $20 \mathrm{MHz}$ tot $820 \mathrm{MHz}$. Die uitset van die RF-seingenerator was $0 \mathrm{dBm}$.

Die resultate toon drie resonantpunte (181.3 MHz, 367.4 MHz en 601.6 MHz) vir die tremoliet- en kalsietmarmermonster. Die dolomietmonster se resonantpunte is by $177.5 \mathrm{MHz}, 363.6 \mathrm{MHz}$ en 597.8 $\mathrm{MHz}$ vasgestel.

\section{Waarnemings en gevolgtrekkings}

Die parallelplaatkapasitormetode het drie resonantpunte vir albei marmermonsters getoon. Die verskil tussen die monsters was slegs 3.8 MHz. Die resultate kan met toekomstige lesings vergelyk word om te bepaal of die monster tremoliet met kalsiet of dolomiet is. Dit kan ook vir die navorsing van hoë RFdrywingsopwekkers gebruik word, wat vir mineraalveredeling aangewend word. 


\title{
The electrical resonating points of marble
}

The parallel-plate-capacitor method of determining the electrical resonating points of two different types of marble is presented. The samples ( $4 \mathrm{~mm}$ thick) were connected to a vector voltmeter and radio frequency signal generator by means of two copper plates, a power splitter and coaxial cables. This experimental method yielded three similar resonating points for the two samples.

\section{Omrol van veldvoertuie}

\author{
B.P. Uys \\ Departement Meganiese en Lugvaartkundige Ingenieurswese, Universiteit van Pretoria, \\ Lynnwood, Pretoria 0002 \\ bpuys6@gmail.com
}

Die doel van die navorsing wat bespreek word, was om ondersoek in te stel na die omrolgedrag van veldvoertuie. Die studie is gedoen deur gebruik te maak van 'n Land Rover Defender 110 sportnutsvoertuig as eksperimentele voertuig, en ADAMS View as sagtewarepaket.

Die sogenaamde "vishoektoets" is met die basislynvoertuig uitgevoer. Daar is korrelasie verkry tussen die data wat tydens die toetse opgeneem is, en 'n volledige drie-dimensionele model van die voertuig in ADAMS View. Die basislynsuspensie op die voertuig is vervolgens vervang met ' $n$ viertoestand semi-aktiewe hidropneumatiese suspensiestelsel, oftewel $4 \mathrm{~S}_{4}$. Die toetse is herhaal, en korrelasie is verkry tussen die toetsdata en die rekenaarmodel. Die rekenaarmodel, met die basislyn suspensiekarakteristieke vervang met die hidropneumatiese suspensiekarakteristieke, is teen hierdie toetsdata geverifieer.

Die rekenaarmodel is ná korrelasie gebruik om te bepaal watter veer- en demperstellings die effektiefste sal wees om omrol te voorkom. Verder is die model ook gebruik om die effek van rithoogteverlaging op omrolgeneigdheid te bepaal. Die hoeveelheid wat die wiele oplig, is as norm vir omrolgeneigdheid gebruik. Ander parameters, soos giersnelheid, rolsnelheid en rolhoek is ook ondersoek.

Implementering van die optimum veer- en demperstellings verminder die hoeveelheid rolhoek met ongeveer $54 \%$, rolsnelheid met $44 \%$, wiellig agter met $75 \%$ en wiellig voor met $10 \%$, relatief tot die basislynsuspensie. 'n Verlaging van $25 \mathrm{~mm}$ in rithoogte verminder die hoeveelheid rolhoek en rolsnelheid met ongeveer $6 \%$, wiellig agter met $28 \%$ en wiellig voor met $9 \%$.

Uit die studie is dit duidelik dat die $4 \mathrm{~S}_{4}$, met die moontlikheid van verstelling aan rithoogte, sinvol aangewend kan word om omrolgeneigdheid te verminder.

\section{Rollover of off-road vehicles}

The study presented investigates the rollover behaviour of off-road vehicles. A Land Rover Defender 110 was used as test vehicle, with ADAMS View as simulation software. The baseline suspension was replaced with a hydro-pneumatic, four-state, semi-active suspension system $\left(4 \mathrm{~S}_{4}\right)$, and the spring and damper settings that would be most effective in reducing rollover propensity were determined by simulation. 


\title{
Die skeiding van sirkonium en hafnium deur middel van vloeistof-vloeistof-ekstraksie
}

\author{
D.J. van der Westhuizen ${ }^{1}$, O.S.L. Bruinsma*1 ${ }^{*}$ EN G. LaChMAnN ${ }^{2}$ \\ ${ }^{1}$ Skool vir Chemiese en Mineraal Ingenieurswese, Noordwes-Universiteit, Privaatsak X6001, \\ Potchefstroom 2520 \\ ${ }^{2}$ Skool vir Chemie, Noordwes-Universiteit, Privaatsak X6001, Potchefstroom 2520 \\ *dolf.bruinsma@nwu.ac.za
}

Sirkonium (Zr) is 'n metaal wat 'n baie lae absorpsievermoë vir termiese neutrone besit, wat beteken dat dit nie die neutrone waaraan dit blootgestel word absorbeer nie. Hierdie chemiese eienskap maak dit ' $n$ gesogte konstruksiemateriaal vir brandstofelemente in kernreaktore. Die primêre bron van $\mathrm{Zr}$ is sirkoonerts $\left(\mathrm{ZrSiO}_{4}\right)$ wat ongeveer $1 \% \mathrm{Hf}$, relatief tot $\mathrm{Zr}$ bevat. Maar om $\mathrm{Zr}$ in kernreaktore te kan gebruik, moet dit eers van hafnium (Hf) gesuiwer (<100 dpm) word, omdat Hf 'n 600-keer groter absorpsievermoë vir termiese neutrone as $\mathrm{Zr}$ het, en dus verskillende kerneienskappe besit.

Hf is baie nou verwant aan $\mathrm{Zr}$ in chemiese gedrag en dit is dus moeilik om hulle chemies te skei. Hierdie verwantskap tussen die twee elemente kan toegeskryf word aan die konfigurasie van die valenselektrone $4 d^{2} 5 s^{2}$ en $5 d^{2} 6 s^{2}$ van $Z r$ en Hf onderskeidelik, en aan die noue verwantskap in ioonstraal van die $\mathrm{M}^{4+}$-ione $\mathrm{Zr}^{4+}(0.084 \mathrm{~nm})$ en $\mathrm{Hf}^{4+}(0.083 \mathrm{~nm})$. Die laasgenoemde het lantanied-inkrimping tot gevolg. ${ }^{1}$

'n Alternatief vir die tradisionele metodes soos TBP, MIBK en die CESUS-proses wat al lank in gebruik is maar ook baie nadele het, ${ }^{2,3}$ is die vloeistof-vloeistof-ekstraksie van kaliumheksafluorosirkonaat $\left(\mathrm{K}_{2} \mathrm{Zr}\left(\mathrm{Hf}_{\mathrm{f}} \mathrm{F}_{6}\right)\right.$.

Die verbinding word uit sirkoonerts vervaardig, deur gebruik te maak van plasmategnologie wat deur $\mathrm{Necsa}^{4}$ ontwikkel is. Tydens die plasmaproses word die chemies inerte sirkoonerts gedissosieer na 'n chemies meer reaktiewe produk - plasma-gedissosieerde sirkoon (PGS) - deur die kristalstruktuur tot amorfe silika af te breek.

Daar word in die literatuur voorspel ${ }^{5}$ dat tydens die skeiding van $\mathrm{Zr}$ en $\mathrm{Hf}$ met tersiêre en kwaternêre amiene as ekstraheermiddels (Aliquat 336 en Alamine 336 onderskeidelik) die ekstraksie van die twee metale via 'n anioonuitruilmeganisme sal plaasvind. Hierdie ekstraksies vind plaas in die teenwoordigheid van hoë chloriedioonkonsentrasies in die waterfase en sikloheksaan word gebruik om die amiene te verdun vir die voorbereiding van die organiese fase.

Die verdeling van $\mathrm{Zr}$ en $\mathrm{Hf}$ tussen die organiese en waterfases word bepaal deur skudproewe te neem, waar die invloed van verskillende sure en oplosmiddels, suur- en ekstraheermiddelkonsentrasies, temperature en faseverhoudings, sowel as die eienskappe van die stropingsvloeistof, bepaal word. Hierdie data word dan gebruik om die tegnologie tot 'n ekonomies industriële proses te optimaliseer.

\section{Verwysings}

1. Nielsen, R.H., Schlewitz, J.H., Nielsen, H. 2001. Kirk-Othmer Encyclopedia of chemical technology, $5^{\text {th }}$ ed, John Wiley. Chapter 26:621-663.

2. Poriel, L., Favre-Réguillon, A., Pellet-Rostaining, S., Lemaire, M. 2006. Zirconium and hafnium separation, part 1. Liquid/liquid extraction in hydrochloric acid aqueous solution with aliquat 336. Separation Science and Technology, 41:1927-1940.

3. Da Silva, A.B.V., Distin, P.A. 1998. Zirconium and hafnium separation without waste generation. CIM Bulletin: Technical Paper, 91:221-224.

4. Nel, J.T. 1999. Process of reacting zirconium based material. U.S. Patent. 5958355. Sep 28. 
5. Vinarov, I.V. 1967. Modern methods of separating zirconium and hafnium. Russian Chemical Reviews, 36(7):522-536.

\section{The separation of zirconium and hafnium by means of solvent extraction}

In the extraction of $\mathrm{Zr}$ and $\mathrm{Hf}$ by solutions of tertiary and quaternary amines, namely Alamine 336 and Aliquat 336 respectively, the extraction of the salts proceeds via an anion-exchange mechanism. The influence of different acids and solvents, as well as acid concentration, solvent concentration, phase ratio and stripping liquids have been investigated.

\section{Die ko-adsorpsie van H en CO op 'n model-ysteroppervlak}

\section{P. van Helden en E. van Steen}

Sentrum vir Katalise-navorsing, Departement Chemiese Ingenieurswese, Universiteit van Kaapstad, Privaatsak X3, Rondebosch 7701

pieter.vanhelden@uct.ac.za

In die konteks van Fischer-Tropsch (FT)-katalise is die adsorpsie van sintese-gas $\left(\mathrm{H}_{2}\right.$ en $\left.\mathrm{CO}\right)$ 'n kritieke stap in die meganisme om lang-ketting-koolwaterstowwe te vorm. Aangesien ystergebaseerde katalisators industrieel in Fischer-Tropsch-sintese gebruik word, is die adsorpsie van sintese-gas op ysteroppervlakke belangrik vir die oppervlakwetenskap en die industrie.

'n Aantal eksperimentele en teoretiese studies oor die afsonderlike adsopsie van waterstof en $\mathrm{CO}$ is reeds vantevore onderneem. Daar is gevind dat waterstof dissosiatief adsorbeer en dat dit baie mobiel op die ysteroppervlak is. ${ }^{1,2}$ Die direkte invloed wat waterstof op die geadsorbeerde CO het, word egter nie goed verstaan nie, alhoewel daar voorheen al eksperimentele adsorpsiestudies op ysteroppervlakke gedoen is. . $^{3-6}$

In hierdie studie het ons die digtheidsfunksionaalteorie ${ }^{7}$ op die $\mathrm{Fe}(100)$-oppervlak toegepas om die ko-adsorpsie van $\mathrm{CO}$ en waterstof te bestudeer. Verskeie oppervlakbedekkings van $\mathrm{CO}$ en waterstof is in ag geneem en gevolglik wissel die $\mathrm{H}: \mathrm{CO}$ verhouding tussen 0.25 en 4 .

Vanuit die berekende ko-adsorpsie-energieë kon daar afgelei word dat die meeste van die koadsorpsie-geometrieë stabiel is by 'n CO-dekking van 0.25 en 0.5 ML. By hoër dekkings is daar gevind dat sekere ko-adsorpsie-geometrieë onstabiel is relatief tot die gasfase. Oor die algemeen is $\mathrm{H}$ onstabiel in die top-posisie; die holte-posisie is die mees gunstige posisie. Die waterstofatome en die O-atoom van die CO ervaar 'n sterk afstotende krag wanneer hulle naby aan mekaar geplaas word. LDOS-grafieke vir 'n aantal van die ko-adsorpsie-geometrieë is gebruik om te toon hoedat die Hatoom se interaksie met die $\mathrm{CO}$ deur die ysteroppervlak-substraat plaasvind.

'n Paar onverwagte ko-adsorpsie-geometrieë is ook ontdek. 'n $\mathrm{HCO}$ - en 'n $\mathrm{H}_{2} \mathrm{CO}$-adsorpsiespesie wat albei stabiel relatief tot die gasfase is, is ontdek, alhoewel hierdie strukture minder gunstig is as die ander ko-adsorpsie-geometrieë. 'n Soortgelyke HCO-struktuur op Rh(111) is al voorgestel. ${ }^{8}$

'n Analise van die vermengingshitte ( dat, alhoewel die meeste van die ko-adsorpsie-geometrieë stabiel is, slegs 'n klein aantal geometrieë by 'n lae oppervlaksdekking in 'n gemengde (ko-geadsorbeerde) toestand stabiel is. Dit verander wanneer die nulpunt-energie-korreksies bygevoeg word, waarna daar slegs een geometrie gevind is wat effens gunstiger in 'n gemengde toestand is. Met die verdere toevoeging van vibrasionele entropie tot die model, is die Gibbs vrye-energie van die oppervlak-vermengingsreaksie bereken. ${ }^{10,11}$ Dit het getoon dat die vermenging van $\mathrm{H}$ en $\mathrm{CO}$ slegs gunstig by temperature laer as ongeveer $380 \mathrm{~K}$ 
is. Dit is benede die werkbare temperatuuromvang van die FT-reaksie (480-600 K), wat aandui dat die waterstof en $\mathrm{CO}$ teen FT-temperature meestal sal neig om as aparte eilande op die ysteroppervlak geadsorbeer te wees. Dit sal die oorwegings vir die meganismes van CO-hidrogenasie op ysterkatalisators beïnvloed.

\section{Verwysings}

1. Jiang, D.E., Carter, E.A. 2003. Surface Science, 547:85-98.

2. Sorescu, D.C. 2005. Catalysis Today, 105:44-65.

3. Wedler, G., Colb, K., Heinrich, W., McElhiney, G. 1978. Applications of Surface Science, 2:85-101.

4. Benzieger, J.B. Madix, R.J. 1982. Surface Science, 115:279-289.

5. Burke, M.L., Madix, R.J. 1990. Surface Science, 237:20-34.

6. Merrill, P.B., Madix, R.J. 1992. Surface Science, 271:81-84.

7. Parr, R., Yang, W. 1989. Density-functional theory of atoms and molecules. Oxford University Press.

8. Inderwildi, O.R., Jenkins, S.J., King, D.A. 2007. Journal of the American Chemical Society, 129:17511759.

9. Ciobica, M., Kleyn, A.W., Van Santen, R.A. 2003. Journal of Physical Chemistry B, 107:164-172.

10. Li, H., Jensen, J.H. 2002. Theoretical Chemistry Accounts.

11. Loffreda, D. 2006. Surface Science, 600:2103-2112.

\section{The co-adsorption of $\mathrm{H}$ and $\mathrm{CO}$ on a model iron surface}

In this study we used a DFT model of the Fe(100) surface to study the co-adsorption of CO and hydrogen. At low CO coverage, most of the co-adsorption geometries are stable in terms of energy. Upon inclusion of the zero-point energy corrections and vibrational entropy, the mixing of $\mathrm{H}$ and $\mathrm{CO}$ is only favoured below $380 \mathrm{~K}$. 